\title{
Investigating the Effect of Formation of Communicative and Pragmatic Competence in Phraseology in Educating Foreign Philological Students
}

\section{Investigar el efecto de la formación de competencia comunicativa y pragmática en fraseología en la educación de estudiantes filológicos extranjeros}

\author{
Natalia V. Chernov \\ Peoples' Friendship University of Russia (RUDN University), Moscú, Rusia \\ ORCID: https://orcid.org/0000-0002-6542-4520 \\ Svetlana A. Zyryano \\ Peoples' Friendship University of Russia (RUDN University), Moscú, Rusia \\ ORCID: https://orcid.org/0000-0002-6147-8986 \\ Elena A. Vukolo $\mathbb{D}_{1}$ \\ Peoples' Friendship University of Russia (RUDN University), Moscú, Rusia \\ ORCID: https://orcid.org/0000-0002-9088-8378
}

Received 12-28-19 Revised 01-25-20 Accepted 03-14-20 On line 16-03-20

*Correspondence

Email: chernova_nv@mail.ru
Cite as:

Chernova, N. V., Zyryanova, S. A., \& Vukolova, E. A. (2020). Investigating the Effect of Formation of Communicative and Pragmatic Competence in Phraseology in Educating Foreign Philological Students. Propósitos y Representaciones, 8(2), e480. Doi: http://dx.doi.org/10.20511/pyr2020.v8n2.480 


\section{Summary}

This article deals with the analysis of the factors influencing the formation of communicative and pragmatic competence in the process of teaching foreign students of the Faculty of Philology, Department of Russian Phraseology. The authors prove that the system of training future teachers of Russian has no sections and courses aimed at the formation of communicative and pragmatic competence in Russian phraseology. The study of the assimilation of phraseological units was carried out in several stages. The first is related to the definition of the level of knowledge of the phraseological system of the Russian language. The second is the level of understanding of certain phraseological units by philology students. The third is the ability to express an evaluative attitude towards someone using phraseological units. The fourth is related to the ability to use phraseological units when evaluating something, any event, phenomena.

Keywords: Russian Phraseology; Communicative and Pragmatic Competence; Foreign Students.

\section{Resumen}

Este artículo aborda el análisis de los factores que influyen en la formación de la competencia comunicativa y pragmática en el proceso de enseñanza de estudiantes extranjeros de la Facultad de Filología del Departamento de Fraseología Rusa. Los autores demuestran que el sistema de formación de futuros profesores de ruso no tiene secciones y cursos destinados a la formación de competencias comunicativas y pragmáticas en la fraseología rusa. El estudio de la asimilación de unidades fraseológicas se realizó en varias etapas. El primero está relacionado con la definición del nivel de conocimiento del sistema fraseológico de la lengua rusa. El segundo es el nivel de comprensión de ciertas unidades fraseológicas por parte de los estudiantes de filología. El tercero es la capacidad de expresar una actitud evaluativa hacia alguien usando unidades fraseológicas. El cuarto está relacionado con la capacidad de usar unidades fraseológicas al evaluar algo, cualquier evento, fenómeno.

Palabras clave: Fraseología rusa; competencia comunicativa y pragmática; Estudiantes extranjeros.

\section{Introduction}

One of the primary tasks facing the teacher of Russian as a foreign language is to teach philology students Russian phraseology. This is due to the great difficulties a foreign audience encounters during lecture courses. The lecturer, no matter how he/she minimizes the number of set expressions, cannot completely do without them, just as he/she cannot (due to the time limit) provide the necessary interpretation and explanation (Kargina, Fisenko, \& Polyanskaya, 2017; Polyanskaya, Polyanskaya, Nikolaevna, Sergeevna, Valeryevna, \& Adonina, 2017; Molotkov, 1986; Royzenzon, 1965; Reference book on Russian phraseology for foreigners, 1997).

Formation of communicative and pragmatic competence in phraseology among foreign philological students, however, goes hand in hand with a number of problems. First, the ostensibly simple question in polling is highly difficult to solve due to the lack of both a large audience, necessary for the experiment and a stable program that would clearly indicate the place and time for studying phraseology. As the analysis of educational programs shows, there is no separate course "Phraseology of the Russian Language" in the system of language training for foreign students, and the practical training of oral and written speech has no separate sections on phraseology. Another impractical thing is to determine the time recommended for the study of Russian phraseological units. Consequently, it is impossible to conduct a survey or questionnaire corresponding to the planned study of this linguistic layer. The identification of phraseological competence in linguistically mixed groups of foreign students is often 
reduced to an individual survey, which does not allow determining the main directions in the study of phraseology and units that are relevant to the Russian language consciousness but causing in foreigners difficulties of comprehension.

In order to identify the level of proficiency in phraseological units gained by foreigners during their study, we conducted a survey that involved 63 foreign philology students of the Peoples' Friendship University of Russia.

The study of the formation of the communicative and pragmatic competence of foreign students was carried out in several stages.

\section{At the first stage, we had to determine the level of knowledge of the phraseological system of the Russian language}

In order to identify the level of proficiency in phraseological units gained by foreigners during their study, we conducted a survey that involved 63 foreign philology students of the Peoples' Friendship University of Russia. Students should answer the question "What Russian phraseological units do you know?" in writing.

The subjects' comprehension of phraseological units was studied. Perceiving the world, a person at stage 1 (first vision) assesses not the object but rather the attitude towards it; the subjects form "questions to the object" in the language of emotional and evaluative coordinates. Of particular interest is the fact that the first-vision stage, when an object is defined by a set of emotional and evaluative properties, turns out to be associated with the process of figurative generalization, one of which is an associative description language. The linguistic units of figurative metaphorical nature, as psycholinguistics shows, are used to form the attitude (emotions and evaluations) of the subject to the described object. The meaning of phraseological units includes a figurative representation, usually supported by the presence of a homonymous phrase. However, the phraseological units differ from homonymous phrases in their potential figurativeness, which is one of the basic properties of phraseological units. A distinctive feature of phraseological units is also a phraseological abstraction, which specificity is that the meaning of phraseological units results from a high degree of abstraction from the direct nominative meanings of homonymous lexical units.

To study the comprehension of phraseological units, the students were proposed to determine the meaning of the specified phraseological units: "Promptly, write down some words next to each phraseological unit you associate them with".

As a result, it turned out that some subjects do not consider phraseological units as an integral figurative unit, but understand only the direct meaning of the individual components of phraseological units.

For example, they understood a phraseological unit 'дать голову на отсечение' as 1) 'go bail for something'; 2) 'make guilty of oneself'; 3) 'let one's head cut'; 4) 'die for anything'.

A phraseological unit 'мозолить глаза' - 1) 'annoy', 2) 'be always before someone's eyes'; 3) 'fuss around', 4) 'stare for a long time'; 5) 'strain eyes'.

A phraseological unit язык проглотить - 1) 'was silent'; 2) 'went silent'; 3) 'silent';4) 'said nothing'; 5) 'bad at speaking'. 
A phraseological unit рубить с плеча - 1) 'hit very hard' "; 2) 'do something rashly, without thinking'; 3) 'do something with great effort'; 4) 'fast'; 5) 'recklessly'; 6) 'hit so as to immediately break'.

A phraseological unit wet behind the ears - 1) 'young'; 2) inexperienced; 3) 'did not wash after breakfast'.

The results of this experiment showed that $78 \%$ of the subjects were able to identify the associative-figurative semantic element, i.e. demonstrated reciprocal mental activity aimed at achieving the goal, motive.

Twenty-two percent of subjects had difficulties with comprehension due to the fact that each phraseological unit, like a word, in speech manifests such properties as polysemy and homonymy. In other words, depending on the context of use, the same term may convey unequal content. The speech contexts and specific communicative situations in the course of perception allow the addressee of communication to choose from a variety of semantic options of phraseological units the one the speaker implies.

Thus, a significant role in understanding phraseological units is played by the reciprocal mental activity of the addressee, which triggers the mechanism of proactive understanding, prediction in speech activity.

Understanding phraseological units can be considered as one of the indicators of the development of linguistic thinking and the formation of communicative and pragmatic competence. Phraseological units are a kind of means of intellectual development: they contribute to a better orientation in non-standard situations, an independent search for the necessary generalization, masked by bright but insignificant particulars.

\section{At the second stage, we determine the level of understanding of phraseological units by communicants}

The students had to answer the question "How do you understand the meaning of these phraseological units?" Here are some results of a written survey:

China, 3rd year; CAR, 2nd year; Chad, 2nd year; Mongolia, 4th year; Korea, 2nd year; the Philippines, 2nd year; Indonesia, 4th year; Senegal, 4th year.

Thus, only 21 of 63 survey participants gave the exact interpretation of phraseological units. There are examples showing a complete lack of understanding of the semantics of phraseological units, sometimes due to interference or because of the direct comprehension of phraseological units.

In the process of enhancing memory and reproducing well-known phraseological units, students have associations that help to remember familiar Russian idioms, that is, such a task in questioning carries both informative and methodological functions that contribute to the formation of communicative and pragmatic competence in phraseology in foreign philology students. (Kornilova, Matveenko, Fisenko, \& Chernova, 2015; Shakhsuvarova, 1983; Shepherd, 2003; Zimin, 1994; Shansky, 1972).

The survey data processing helped to draw certain conclusions about the range of foreigners' acquaintance with Russian phraseology, about the degree of adequate/inadequate understanding of the meaning of phraseological units and, finally, the ability to introduce these phraseological units into speech.

The results of the survey can be presented in the following table, where a, b, c, d present the characteristics of the students' response: a) - the answer contains a correct understanding of the meaning of phraseological units; b) - misunderstanding of the meaning of phraseological units; c) incomplete understanding (direct meaning only); d) - the effect of interference. 


\begin{tabular}{|c|c|c|c|c|c|c|c|c|c|c|c|c|c|}
\hline \multirow[t]{2}{*}{ Year } & \multirow[t]{2}{*}{ Number of students } & \multicolumn{4}{|c|}{ question 1} & \multicolumn{4}{|c|}{ question 2} & \multicolumn{4}{|c|}{ question 3} \\
\hline & & $\mathrm{a}$ & $\mathrm{b}$ & $\mathrm{c}$ & $\mathrm{d}$ & $\mathrm{a}$ & $\mathrm{b}$ & $\mathrm{c}$ & $\mathrm{d}$ & $\mathrm{a}$ & $\mathrm{b}$ & $\mathrm{c}$ & $\mathrm{d}$ \\
\hline II & 20 & 18 & 5 & 4 & - & 8 & 9 & 6 & 2 & - & - & - & - \\
\hline III & 24 & 17 & 2 & 7 & - & 10 & 5 & 1 & 1 & 10 & 5 & 4 & 2 \\
\hline IV & 19 & 32 & 3 & 6 & - & 29 & 3 & 1 & 1 & 29 & 3 & 1 & - \\
\hline
\end{tabular}

\section{At the third Stage}

At the third Stage the experiment was focused on identifying the relationship to an object (person) with the help of phraseological units.

The study of attitudes is closely connected with the study of human emotions since the integration of emotional responses to the object of interest gives rise to a certain attitude towards it.

However, the emotional reaction of the speaker/addressee can only be described as an experienced emotion, that is, a feeling.

Therefore, the subjects were offered the following task: "Write the phraseological units you use to express certain feelings".

The questionnaires presented such feelings as admiration, joy, interest, indifference, disinterest, irritation, annoyance, contempt, resentment, fear, etc.

Examples of phraseological units the subjects use to express joy and admiration, that is, a positive attitude to something, were: to be (feel) in the seventh heaven, to be (feel) on top of bliss, without memory, for your pleasure, in joys, outside of yourself (from joy), think only, perk up, be born under a happy star.

A negative attitude - contempt, neglect, irritation - was expressed using the following phraseological units: поднимать на смех, скалить зубы, бросать камешки в огород.

In addition to a negative and positive attitude, a person is known to experience a neutral attitude, i.e. indifference, disinterest.

The students listed the following phraseological units: stand aside, wave your hand, neither hot nor cold.

Although this information is not directly related to our problem, it implicitly gives an idea of the complexity of comprehending, understanding and mastering phraseological units even among native speakers.

We found it necessary to consider in detail the proposed experiment (more exactly, a questionnaire, since such a designation is somewhat arbitrary), because the general, highly valuable results of this work can serve both as statistical data and as informative material giving understanding of the level of knowledge and an adequate/inadequate understanding of phraseology by non-philology students and students of high schools and lyceums.

The stages of the work done can to some extent be used in the survey of foreign students.

The results of the experiment are important in the sense they indicate the complexity of perception and awareness of the semantics of such a key element in the language as a phraseological unit. In that part of the work where it was necessary to 
differentiate the direct and secondary (metaphorical) meaning of phraseological units, only $2 / 3$ of the subjects were able to determine the meaning of its internal form.

As in most cases, when dealing with phraseology at the lexicographic and methodological level, the problem of minimizing the material was important, but this study did not give it sufficient reasoning. reliability.

The indication of the time (duration of the experiment) confirms its scientific

We should immediately note that such work with foreigners is carried out with a significant increase in all temporary indicators, and the problem of selecting phraseological units comes to the fore.

\section{At the fourth Stage}

At the fourth Stage Students' ability to use phraseological units to evaluate something was studied. For example, phraseological units с гулькин нос has two meanings in the phraseological dictionary: 1) 'very few'; 2) 'very small, tiny'. Understanding by the subjects: 'very small'.

A phraseological unit to take it personally has the following dictionary meanings: 1) 'to perceive something with increased sensitivity, giving too much importance to something'; 'to worry strongly about something'; 2) 'treat anything with great interest'. Understanding: 'be overly concerned with something'.

A phraseological unit like water off a duck's back is defined in a phraseological dictionary as follows: 1) like water from a goose to someone - a piece of cake, indifferent; makes no impression, does not affect anyone, does not do anything to someone; 2) like goose water from someone - easily, quickly, disappears without a trace, something is forgotten by someone.

\section{Understanding: 'does not matter, indifferent'}

A phraseological unit head is spinning has the following dictionary definitions: 1) 'someone is dizzy (due to fatigue, etc.)'; 2) 'someone loses the ability to clearly think due to a variety of cases, worries, experiences, etc.'

\section{Understanding: 'overstress, fatigue due to a lot of work'}

A phraseological unit бросать тень is defined as follows: 1) 'sadden something'; 2) 'vilify, denigrate someone or something'.

\section{Understanding: 'vilify, slander someone'}

Forty-three percent of the subjects found a rather approximate meaning of a phraseological unit. When explaining the phraseological units, they used situational moments, their life experiences.

A phraseological unit the head (bowler) is cooking has the following dictionary definitions: 'someone is smart, quick-witted, intelligent'. The meaning defined by the subjects: 'to be good at any subject'.

A phraseological unit turn up hot is understood to mean: 'get into trouble with an excited, irritated, angry person'. The subjects understand this phraseological unit as follows: 1) 'punishment by parents'; 2) "one is fighting, and another butts into the fight and catches it bad'. 
A phraseological unit fool around. Dictionary meanings: 1) 'fool around, clown around, entertain with silly tricks'; 2) 'do stupid things; do wrong'; 3) 'waste, idle time'.

\section{The subjects understand it as 'do nothing, idle'}

A phraseological unit приходить (прийти) в голову means: 1) 'to arise, appear in someone's consciousness'; 2) 'to think, to imagine, to reach someone's consciousness'; 3) 'want, desire, intend'.

\section{The subjects understand it as 'to think about something, to think of something'.}

A phraseological unit хлопать ушами: 1) 'listen to something, not understand, not perceive what is being said'; 2) 'daydream, take no measures'.

The meaning defined by the subjects: 'pay no attention to anything': A phraseological unit hold your hands at the seams means: tremble, stand in awe of someone. The meaning defined by the subjects: 'stand still, quietly'.

A phraseological unit лицом клицу: 1) 'very close, in close contact'; 2) 'directly, closely (meet, collide)'; 3) 'directly, truly seriously (touch, collide)'.

The meaning defined by the subjects: 'face to face': A phraseological unit like clockwork 'swimmingly, without difficulty and complications'. The meaning defined by the subjects: 'very good'.

A phraseological unit сбить с толку. 1) 'disconcert, distract, misinform, confuse'; 2) 'by acting in any way, induce to change the behavior in a bad way, push for something bad'.

\section{The meaning defined by the subjects: 'confuse someone, hinder someone from thinking'.}

Operations on the identification and comparison of structures of meaning allow us to see not only the set of knowledge about the world contained in the semantic memory of a person but also the cognitive abilities of a dynamic nature - the handling strategies for ready-made knowledge structures.

In the associative relation, semantic links of phraseological units with other linguistic signs in speech appear as a set of parallel options. Associations with the previously spoken words, objects, situations, as well as conjugations of the type of connotations are possible. The number of these lexical and psychological mediations can continue.

\section{Conclusion}

Thus, the formation of communicative and pragmatic competence in phraseology among foreign philological students is a complex mental process associated with the linguocultural component. Consideration of the specific features of linguistic characteristics of phraseological units, as well as the specifics of teaching Russian as a foreign language in the Faculty of Philology, due to the special interest of foreigners in the phraseological fund of the Russian language and its analysis in their native language. A particularly important for the philological audience is the study of the phraseological image underlying the phraseological unit. The study of the similarities and differences in the figurative structure of a phraseological unit should be an obligatory preliminary component of the linguistic-methodical system for the presentation of a phraseological unit. Therefore, highlighting symbolic words common to two languages - the target and the students' native languages - assumes greater importance. 


\section{References}

Kargina, N. V., Fisenko, O. S., \& Polyanskaya, E. N. (2017). Technology of social manament in organization in the Russia federation: the theoretical aspect. The Turkish online Journal of Design Art and Communication TOJDAC, 8(3), 1970-1979.

Kornilova, T. V., Matveenko, V. E., Fisenko, O. S., \& Chernova, N. V. (2015). The role of audio and video means in the training of foreign philologists concerning national vocabulary of russian language. Journal of Language and Literature, 6(4), 390-392.

Molotkov, A. I. (1986). Phraseological dictionary of the Russian language. The alphabet. Polyanskaya, E. N., Polyanskaya, F., Nikolaevna, E., Sergeevna, F. O., Valeryevna, A. L., \& Adonina, L. V. (2017). Social values in management of social work. Journal of Engineering and Applied Sciences, 9(1), 23-34.

Reference book on Russian phraseology for foreigners (expression of emotions). (1997). M.: Publishing House of Moscow University, p. 90

Royzenzon, L. I. (1965). Internal form of a word and internal form of a phraseological unit. phraseology Questions. Tashkent: Science, 8(3), 47-59.

Zimin, S. D. (1994). Russian proverbs and sayings: Educational dictionary. Ashurova and others. M.: School-Press, p. 320

Shakhsuvarova, E. M. (1983). Linguistic and methodological aspects of the description of phraseology of Russian for training of foreign pupils at the initial stage. Avtoref. Dissertation. Russia.

Shansky, N. M. (1972). Lexicology of modern Russian language. Russia: Education.

Shepherd, V. P. (2003). Vremya of inclusion of phraseological units in process of training in Russian, criteria of their selection and ways of interpretation. Materials X Kogressa MAPRYAL, pp. 192-195.

\section{Acknowledgements}

The publication has been performed with the support of the "RUDN University Program 5-100" 